NBER WORKING PAPERS SERIES

INVESTMENT POLICIES IN THE GATT

Rachel Mcculloch

Working Paper No. 3672

NATIONAL BUREAU OF ECONOMIC RESEARCH

1050 Massachusetts Avenue

Cambridge, MA 02138

Apri1 1991

This paper is part of NBER's research program in International studies. Any opinions expressed are those of the author and not those of the National Bureau of Economic Research. 
NBER Working Paper \#3672 April 1991

\section{INVESTMENT POLICIES IN THE GATT}

\section{ABSTRACT}

Host country policies toward inward direct investment can have predictable effects on trade flows. "Trade related investment measures" (TRIMS) such as local-content requirements and minimum-export requirements have recently come under official scrutiny in the General Agreement on Tariffs and Trade. This paper examines the economic and political context of the Uruguay Round negotiations on TRIMs. In the negotiations, investment measures have been treated as a particular instance of a broader problem: the proliferation of nontariff trade distortions. As with other trade distortions, the negotiating strategy has been to identify specific policies to be proscribed or limited. However, this approach ignores the typical interactions between multinational firms and host governments. Observed investment regimes are often the result of a lengthy and complex bargaining process. While some investment regimes actually alter the allocation of resources in production and trade, others affect mainly the distribution of rents between firms and host countries. In particular, the trade impact, if any, depends as much on economic conditions as on the specific combination of investment measures imposed.

Rachel McCulloch Department of Economics Brandeis University waltham, MA 02254 


\section{Rachel McCulloch}

Nearly all countries make efforts to attract inward direct investment. At the same time, most also impose limits on access and otherwise restrict the activities of foreign-controlled companies within their borders. This carrot-and-stick approach can have important consequences for the location of economic activity and for the efficiency of that activity in any given location. In particular, investment policies can have predictable effects on trade flows similar to those of policies aimed explicitly at trade: reducing imports, expanding exports, or both.

Along with other nontariff measures that influence trade flows, investment policies have become more conspicuous in recent decades. As successive rounds of negotiations within the General Agreement on Tariffs and Trade (GATT) have achieved major reductions in the role played by the more straightforward trade-influencing policies, a major but unanticipated result has been expanded use of investment measures and other "opaque" forms of protection as alternative means to achieve national objectives. Because of this substitution, the central trade-liberalization goal of the GATT may not be attainable without limits on at least some types of national policies toward direct investment. 
The Uruguay Round was the first GATT round to attempt negotiations on policies toward foreign direct investment. While some past agenda items (e.g., subsidies) have been comparable in their importance to members' perceived ability to control economic activity within their borders, none has been such a core issue in terms of national sovereignty. In the case of direct investment, the policies in question are aimed specifically at controlling the extent and character of foreign production within the nation's own boundaries. Moreover, by its very nature, direct investment tends to be concentrated in sectors of the economy that conform least well to the paradigm of perfect competition. Thus, standard arguments for free trade are least likely to apply without significant qualification.

This paper examines the economic and political context of the Uruguay Round negotiations on investment measures. Within the GATT, investment measures have been treated as a particular instance of a broader problem: the proliferation of nontariff trade distortions. However, this approach ignores the interaction between multinational firms and governments that is typical when host countries seek to regulate direct investment. Observed investment measures are often the end result of a bargaining process. A central issue is whether investment regimes actually alter the allocation of resources in 
production and trade or merely the distribution of rents between firms and host countries. The analysis in this paper underscores that trade impact depends as much on economic conditions as on the specific combination of investment measures imposed.

\section{GATT INITIATIVES ON INVESTMENT}

Given its nature and purpose, the GATT is far from being the obvious forum for discussion of issues related to foreign direct investment (FDI). Indeed, inclusion of investment policies on the agenda for the Uruguay Round negotiations was itself a major break with past practice and strongly opposed by some capital-importing nations. In the Uruguay Round, consideration has been limited to a subset of investment policies known as "trade related investment measures" (TRIMs). These include local content requirements, minimum export requirements, and similar regulations tied specifically to the trade practices of multinational firms, along with other policies that may have a less explicit but nonetheless significant influence on trade flows through their effects on the location of production.

The success of the GATT as a vehicle for promoting open markets for internationally traded goods has rested from the start on a delicate balance between two conflicting goals of member nations: 
securing the acknowledged collective benefits of freer trade and integrated global markets (more precisely and from the mercantilistic perspective of most negotiators, securing improved access to old and new export markets) while sacrificing a minimum of national sovereignty. Until the Tokyo Round, the balance between these goals was achieved by concentrating liberalization efforts on national policy measures that affect goods "at the border," primarily tariffs. Yet the acclaimed success of these efforts in slashing most tariffs brought about notably less success in achieving the ultimate goal of freer trade. Rather, the role of nontariff trade distortions became increasingly prominent.

Some nontariff policies had already been in place but now loomed larger as tariff barriers shrank. To a considerable extent, however, the very success of the GATT in limiting the use of tariffs led member nations to substitute other measures from the shortened menu of allowed policy instruments. In turn, countermeasures initially aimed at these nontariff barriers themselves blossomed into further distortions of trade flows, as in the case of countervailing and anti-dumping duties. The Tokyo Round and Uruguay Round were thus required to tackle a wide range of nontariff policies and practices. Even when this is not their primary intent, these measures can have a significant 
distorting impact on trade flows. ${ }^{1}$

Within the GATT framework, there are two possible approaches to dealing with investment-related issues. The first, already implemented in a number of cases, is to apply existing GATT articles to situations arising from national or subnational investment policies. This approach focuses on the possible trade-distorting effects of the policies rather than the policies themselves. For example, the United States was successful in arguing before a GATT panel that local content requirements imposed by Canada's Foreign Investment Review Agency violated Article XXIII. However, the panel did not agree with the U.S. contention that Canadian export performance requirements for foreign investors violated GATT rules.

The second approach, as pursued in the Uruguay Round by the United States, is to negotiate new agreements that broaden GATT authority to deal with specific policies not previously covered by GATT rules. In practice, this strategy concentrates on enumerating proscribed, suspect, and acceptable policies toward direct investments. But, because a method that singles out unacceptable policies has the proven disadvantage of promoting the substitution of less-transparent alternatives, it may be more the form than the fact of protection which is thereby controlled. The Uruguay Round negotiations on investment 
were initiated at the insistence of U.S.-based multinational firms and labor groups, at a time when policy concerns within the United States were still focused mainly on outward investments by U.S. firms. Complaints highlighted the presumed effects on U.S. production and profits of performance requirements imposed by a number of lessdeveloped host countries and by Canada under the Foreign Investment Review Act.

Ironically, U.S. efforts within the GATT started to bear fruit just when direct investments by European, Canadian, and Japanese firms in the United States had begun a period of rapid growth, and U.S. policy concerns had become more aligned with those of other host countries. By the mid-1980s, the United States had emerged as the world's largest host country in terms of the total value of inward direct investment. Yet the United States continued to be the main advocate of GATT restrictions on TRIMs, even while the Congress contemplated new policies to monitor and regulate the activities of foreign companies within U.S. borders.

\section{A GATT FOR INVESTMENT?}

Proceeding within the GATT framework implies at best a partial remedy for the efficiency losses that may arise from national 
policies toward direct investment. In particular, any GATT action must be justified in terms of significant effects on trade. Rather than trying to shoe-hom investment issues into the GATT framework at all cover the vehement objections of some less-developed host countries), why not treat the problem separately in a logical and comprehensive fashion?

For many years there have been calls for a new international forum that would oversee foreign direct investment in much the way that GATT oversees international trade -- in effect, a GATT for foreign investment, as originally proposed by Goldberg and Kindleberger (1970) and endorsed by many other academic specialists. Such a body would establish a set of rules and dispute-settlement procedures aimed at increasing the global benefits of international investment, just as GATT does -- at least in principle - for national policies governing trade.

The evident reluctance of the United States and other major industrial nations to pursue free-standing multilateral negotiations on investment issues may be rooted in the failure of previous efforts along similar lines. The International Trade Organization (ITO) was designed at the end of World War II to complete the institutional framework for international cooperation that included also the International Monetary 
Fund and the International Bank for Reconstruction and Development (World Bank).

At the urging of the U.S. business community, the ITO draft charter dealt specifically with national policies toward foreign direct investment. But to the eyes of U.S. companies concerned primarily about the security of their property abroad, the actual provisions of the charter appeared to favor the interests of host over source countries. The objections of the U.S. business community were one reason for the eventual failure of the United States to ratify the charter (Spero, 1981). The GATT, as a more limited successor to the ITO, made no attempt to deal with foreign investment issues.

The World Bank's International Center for the Settlement of Investment Disputes (ICSID), established in 1965, remains the only international forum devoted entirely to the settlement of foreign investment issues, but one that is remarkably toothless even relative to other international bodies. Disputes must be submitted voluntarily by both parties, precluding consideration of the most controversial issues. Moreover, the ICSID has no power to enforce its decisions (Lipson, 1985). Yet some Latin American nations have seen even this mildest form of governance as intruding unacceptably on national sovereignty. 
In the early postwar period, as many former colonies became sovereign nations, the prospect for setting up an international regulatory body that could satisfy both host and source countries grew ever more remote. By the 1970 s, the atmosphere in the major international organizations had become openly confrontational; demands for a "New International Economic Order" were pressed by less-developed nations of a somewhat unified "South" upon an unprepared "North" reeling from oil-price shocks. High on the South's agenda were measures to enhance host-country control over multinational corporations.

While the industrial nations were understandably slow to acquiesce to such demands, the increased policy activism of host countries also increased the pressure to provide some form of international governance in this area. The nations of the Organization for Economic Cooperation and Development (OECD) produced a voluntary code of conduct for multinational firms, intended primarily to disavow the most controversial and anticompetitive business practices attributed to multinational corporations. Voluntary codes were also produced by the Center on Transnational Corporations of the United Nations and by the United Nations Conference. on Trade and Development (UNCTAD). 
By the 1980 s, both the investment climate and the prospects for new types of international agreements had begun to improve. The inclusion of investment issues on the Uruguay Round agenda was one reflection of this improvement. After a decade or more of experimentation with aggressive regulation of multinational firms, host countries were concerned as much about competing to attract foreign firms as about controlling their activities. The formerly appealing strategies of expropriation and of "unbundling" direct investment -- i.e., acquiring foreign technology and financial capital without foreign equity participation -- had been somewhat discredited by the generally disappointing results actually achieved by nations implementing them. While policy activism toward direct investment had not been renounced entirely, the carrot-and-stick approach had largely replaced the stick.

A second change that also augured well for progress on international agreements was the increased extent of intraindustry foreign direct investment among the industrialized nations, and especially the United States. This development blurred the distinction, at least among industrial nations, between host and source countries. In the 1960s, the United Ștates was the preeminent and indeed quintessential source country, by far the most conspicuous potential 
beneficiary of limits on nationalistic policies of host countries. By 1990, the United States remained a major source country and the strongest voice for international action to regulate investment policies, yet it had also become the world's most important host to direct investment. The European Community as well as Canada and Japan had gained a corresponding stake in placing limits on host-country investment policies, and particularly those of the United States. The U.S.-Canada Free Trade Agreement, ratified in 1988, in fact went far beyond any multilateral action contemplated in the Uruguay Round. Like other aspects of the agreement, this may be viewed as a "leading indicator" of trends in multilateral negotiations.

Given these developments, the 1990 s may offer the first real opportunity in many decades for comprehensive multilateral negotiations on investment issues. Indeed, while the concept of a GATT for investment remained alive mainly in the academic literature during the 1970 s and 1980 s, by 1990 it had reemerged as a serious proposal for action. ${ }^{2}$ For this reason, I deal with national investment policies somewhat more broadly in this article than was actually undertaken in the Uruguay Round negotiations, while still concentrating on the potential effects of such policies on location of production and trade flows. 


\section{NATIONAL INVESTMENT POLICIES}

Although the universe of policies potentially affecting foreign direct investments is immense, policies relevant to recent international negotiations can be classified into two basic types: incentives for investment and operating restrictions on investment (performance requirements). As extremes, the first type includes the requirement of local establishment for market access, a policy prominent in services, while the second type includes investment prohibitions in specific sectors as well as limits on the percentage of foreign equity ownership. ${ }^{3}$

The Uruguay Round negotiations focused mainly on certain performance requirements -- the policies now known as TRIMs -- that are presumed to have direct effects on trade flows. However, not all TRIMs are binding; non-binding TRIMs may have no effect on trade flows. ${ }^{4}$ Moreover, almost all TRIMs are imposed in conjunction with investment incentives. To the extent that incentives are successful in influencing the location of production, they may be equally, if not as transparently, regarded as trade-related measures. ${ }^{5}$

Despite a perception on the part of some U.S. officials and some U.S.-based companies that TRIMs "constitute one of the most 
serious trade policy problems facing the international trading community" (LICIT, 1981), neither the documented incidence of measures nor available estimates of their trade-distorting effects provide strong support for this position. Although a laissez-faire approach toward foreign investment is clearly the exception rather than the rule among host countries, data from several empirical studies of policy measures with specific trade effects yield surprisingly little consensus on their relative frequency and importance.

A U.S. Department of Commerce study of 24,666 foreign affiliates of U.S. companies found that in 1977 just over a quarter of these benefited from some type of incentives to investment, while on average 14 percent were subject to one or more performance requirement. However, only 2 percent of U.S. affiliates were subject to a minimum export requirement, 3 percent to a maximum import level, 3 percent to a minimum level of local inputs, and 8 percent to a minimum labor local requirement, with about 6 percent overall affected by one or more of these measures CU.S. Department of Commerce, 1981). In sharp contrast, a much smaller but more detailed World Bank study of 74 investments found that more than half were subject to explicit trade-related performance requirements; however, many of these were considered non-binding by the respondents (Guisinger, 
1986, p. 92).

One important finding of the Commerce study in light of subsequent developments in the Uruguay Round was that a much larger percentage of U.S. subsidiaries in less-developed countries were subject to performance requirements than in developed countries. Both the Commerce and World Bank studies confirmed that TRIMs were much more prevalent than average in some manufacturing industries, notably automobiles. These conclusions support the view that lessdeveloped countries rely on investment measures as an integral part of overall industrial-development policies.

A study of 682 investments commissioned by the U.S. Overseas Private Investment Corporation (OPIC) found 40 percent of all OPICsupported projects subject to actual or potential trade-related investment performance requirements. However, because of OPIC policies regarding eligibility, these investments cannot be regarded as a random sample of all U.S. investments either by host country or by industry. In particular, no automobile investment were included. ${ }^{6}$

The studies revealed considerable variation across host countries in preferred policy strategies. Approaches favored by individual host countries ranged from Mexico's explicit published performance requirements, through France's tax breaks tied to job 
creation and exports, to Ireland's cash grants to subsidiaries producing for export (Moran and Pearson, 1988, pp. 121-122). In the United States no fewer than 24 state governments were found to offer investment incentives, prompting the observation that although the United States has no local-content legislation, "it would be disingenuous to suggest that the pursuit by certain states of foreignowned automobile plants has no impact on the country's trade flows" (p. 122). ${ }^{7}$

While diverging markedly on the relative importance of TRIMs, all studies have noted the large number of nearly equivalent policy instruments used by any one host. For example, the World Bank study found that in a group of ten developed and less-developed host countries, governments used an average of 22 different investment policies of various types. Although no government used all available measures in the case of each investment, the average number of instruments per project was "surprisingly high" (Guisinger, 1986, p. 84).

Since an equivalent net incentive could be provided much more simply, some investigators concluded that the nontransparency achieved through multiple and apparently contradictory policy instruments might in fact serve the interests of the host government and perhaps even the 
foreign firm. The availability of multiple incentives and disencentives could enhance the ability of the host to act as a discriminating monopolist, i.e., to extract a larger share of the profits associated with a particular project. On the other hand, an investing firm would be better able to conceal from potential competitors -- and perhaps also from a suspicious public -- the extent of preferential treatment bestowed on its activity.

Even harder to pin down than the extent of TRIMs is the actual effect on subsidiaries subject to these policies. In two-thirds of the projects surveyed in the World Bank study, managers reported that the location decision was affected by incentive policies. However, the question posed was whether the same location would have been chosen in the absence of host incentives but the same performance requirements, and with all investment policies of alternative sites unchanged. Since performance requirements are almost always paired with incentives, and since there is often active competition among localities for new investments, the two-thirds figure is clearly an extreme upper bound on the fraction of investments thus influenced.

Survey evidence suggests a rather minor effect of the performance requirements themselves on exports and imports. Many TRIMs were perceived to be non-binding, while others merely speeded 
up changes in trade that firms would have undertaken even in the absence of the policies. As already noted, such reports may reflect exante versus ex-post optimization by corporations. However, as Safarian (1983, p. 612) has observed, reporting may be incomplete because companies are reluctant to appear critical of "the wielders of regulatory and fiscal power" in host countries.

\section{THE PERSPECTIVE OF THE GLOBALLY INTEGRATED FIRM ${ }^{8}$}

National investment policies, whether of host or source countries, seek to enhance benefits derived from the presence of multinational corporations (MNCs). 9 This may entail rent-shifting, changes in the pattern of production and trade, or some combination of these. While rent-shifting affects primarily the distribution of benefits within and between countries from an investment, changes in the pattern of production or trade may improve overall economic efficiency by correcting a market failure or achieve certain "noneconomic" objectives of policy makers. ${ }^{10}$ To analyze the potential consequences of investment policies, it is useful to begin by considering the role of direct investments in global production and trade, first in a fully infegrated global economy without national boundaries and then in a world divided into sovereign nations. 
In a world without national boundaries or other barriers to the free movement of goods and productive factors, maximization of profits requires minimization of cost. The location of each step in any production process is therefore determined by cost alone, so as to minimize the overall cost of serving any particular market. Depending on scale economies and the relative costs of moving goods versus required inputs, a given process may be carried out at a single location or at many locations around the world.

In a fully integrated global economy, observed trade among regions may be based on classical comparative advantage, scale economies, or a combination of the two. Some firms operate at a single location and carry out only a single process; any required coordination of the activities of individual firms is then achieved entirely through arm's-length (market) transactions. For other firms, coordination of activities in multiple locations is performed by a single management -- "internalized" by the firm, in the language of industrial organization. However, since internalization has costs of its own, the existence of multiple-location or multiple-product firms has to be explained in terms of corresponding increases in efficiency over what could be attained with separate management and market coordination. 
Now contrast production and trade under the more realistic assumption that the world economy is divided into multiple political jurisdictions. A central feature of this case is that profit maximization no longer implies cost minimization. Along with whatever factors determine the cost of serving any given market in a fully integrated economy, location of production in a multi-country world must also reflect any policy-induced elements of profitability, including tariffs and other trade policies, taxes and subsidies, and policies toward foreign investment. These policies can affect profits through either costs or revenues. In particular, higher profits may be associated with both higher revenues and higher production costs, as might occur with induced local production to serve a protected market.

Where does direct investment fit into this scheme? Whenever multiple-location firms span national boundaries, the pattern of profitmaximizing production by definition includes foreign direct investment. However, since firms operating in foreign locations typically incur costs higher than otherwise similar local firms, the existence of such operations again has to be explained in terms of greater firm profitability.

Modem theories of foreign direct investment rest on the existence of a firm-specific advantage that is most profitably exploited 
through managerial control over operations in multiple countries. ${ }^{11}$ This firm-specific advantage may also provide the basis for the existence of multiple-location operations within a single integrated economy. However, because production costs are necessarily minimized in the case of a single integrated economy but not in a multi-country world, it is useful to separate direct investments into three categories.

The first category of investment, which I call cost-driven, consists of those parts of multiple-location operations simply relabeled as foreign direct investments when national boundaries are superimposed on what was previously assumed to be a single integrated economy. 12 Obviously, the newly designated "foreign investors" in this category are a subset of all firms that would engage in multiple-plant operations in the single-economy case. These investments are characterized by strong locational motives along with significant internalization benefits. Extractive industries provide numerous examples of cost-driven investments. Other important categories are consumer services, e.g., retail banking and hotels, and investments complementary to local sales, such as distribution and service facilities. 
Although this category includes all investments not subject to any specific investment policies, an investment would also be appropriately included even when it is subject to investment policies as long as actual production and trade decisions are not affected by the policies. This may be true because the policies are aimed primarily at extracting rents rather than changing production decisions, because policies are not expected to be binding, because policies overall play only a minor role in the firm's decisions relative to other locational advantages or political stability, or because any incentive package offered by one potential host is largely matched by others. The latter two possibilities may apply in the case of "footloosen activities that are the object of active bidding by rival would-be hosts.

The second and third categories consist of those direct investments actually induced by the assumed division of the world into sovereign political jurisdictions, rather than merely relabeled. In the second category, which I call policy-driven, are investments directly influenced by national policies, including those located and operated to serve a protected market, to benefit from favorable tax treatment or other incentives, or to meet local-content requirements applied to existing operations. From the point of view of the firm, such investments represent a second-best response to market fragmentation. 
Most entail substitution between local production and foreign production, with higher production cost to the firm, ${ }^{13}$ and corresponding changes in trade. Many manufacturing investments in both developed and less-developed countries, such as those in electronics and automobiles, belong in this category. Such investments may be either import-substituting or export-oriented.

Investments in the third category, which I call border-driven, are not direct responses to specific policies; rather, they are responses to the fact of multiple political jurisdictions. Such investments have no easily predictable impact on local production, trade, or global efficiency. ${ }^{14}$ Establishment of local production may be a means to enhance the firm's credibility as a market participant, whether in the eyes of consumers or of potential competitors. Also, since production and market conditions in sovereign political units are likely to be less than perfectly correlated, an increase in the extent of direct investment may be part of the firm's risk-management strategy for a multi-country world. Border-driven investments are designed to capture the benefits of being multinational, rather than the advantages of locating the firm's activities in any specific place.

Although it would be impractical to apply this classification to actual investments, the distinctions among the three types provide 
some insight into the issues arising both from national investment policies and from attempts to limit their use. The first two categories of cost-driven and policy-driven investments correspond roughly to two potential objectives of national policy measures: rent extraction (with no intended effect on resource allocation) and resource reallocation. ${ }^{15}$ In cost-driven investments, firm location decisions are unchanged from the case of the integrated world economy. However, the imposition of national boundaries implies potential competition with other tax jurisdictions, as well as with foreign owners and workers, for whatever rents are associated with the firm-specific advantage. Taxes, together with rules on transfer pricing and remittances, are the main policy tools used to extract such rents on behalf of the host (or source) government. ${ }^{16}$ Taxation may have little or no direct effect on production and trade. However, rent may also be extracted implicitly via (binding) performance requirements that reduce firm profits.

For policy-driven investments, rent extraction remains a potential goal of policy makers, but this is achieved in conjunction with changes in global production that are themselves policy-induced. ${ }^{17}$ Since most changes in production move the firm away from its preferred (profit-maximizing) position, only marginal results are likely 
to be achieved without the inclusion of policy measures to enhance firm rents. For example, a tariff may be used to protect the domestic market from imports of a good that would otherwise be supplied from abroad. If the supplying firm possesses a firm-specific advantage sufficiently valuable to offset the greater cost of producing locally, it will now shift the location of some production activity to the host country. ${ }^{18}$

Although somewhat artificial, this classification is helpful in understanding the conflict within the GATT over the appropriate treatment of investment policies. To the extent that investments are cost-driven and policies mainly shift rents without affecting the allocation of resources, there is little resulting impact on trade (or on overall economic efficiency). However, whether this is true in any particular situation depends on both the policies and the underlying economic forces.

Some less-developed countries have therefore argued that the GATT should focus not on the measures themselves, but only on their effects on trade flows, and then only when the resulting impact on trade -- if there is such an impact -- is significant and the resulting injury to other countries sufficiently great to merit a sacrifice of national sovereignty by the host. In contrast, the United States has 
favored an approach that begins by identifying particular measures that may be expected to affect trade -- a kind of "round up the usual suspects" approach. But in either case, if significant trade effects are the criterion for including investment measures in international negotiations, a large set of policies, including most taxes and many types of incentives, is thus omitted entirely from consideration. ${ }^{19}$

\section{THE ECONOMIC CASE FOR INTERNATIONAL ACTION}

As with policies toward trade, in practice national policies aimed at investment tend to reduce global efficiency via suboptimal allocation of resources in production and via associated rent-seeking activities. An important difference, however, is that investment policies are less likely than those aimed directly at trade flows to reduce the country's own aggregate welfare. International cooperation may therefore be even more important than in the case of trade in avoiding a "prisoner's dilemma" situation. ${ }^{20}$

For a country small enough to have no appreciable effect on world prices, the cost of tariff protection is borne almost entirely by the country itself. Even for large countries, the net effect of protection on national welfare is typically negative. But when a tariff creates an incentive for import-substituting direct investment, and investment 
policies are then used to extract some part of the rents generated by foreign-controlled production for the local market, the country may in fact gain. ${ }^{21}$ However, the foreign investor will also gain (or expect to gain), at least relative to the situation of protection but no investment. The corresponding losses, although typically larger in the aggregate, will be spread among other competing suppliers but may be small for any one of them. An important implication is that the "problem" of TRIMs is at least in part a problem of incomplete liberalization of trade. Without tariffs, quotas, and other import barriers, there would be less rent to extract and thus less scope for performance requirements.

Efforts to bring investment policies under GATT discipline have come principally from the United States and have been propelled by the perceived interests of some U.S.-based multinational firms. Yet while there is no question that many U.S.-based firms have been affected by TRIMs, the evidence is far from conclusive that source countries like the United States have been harmed significantly by the use of these policies. In many instances, the host country and the source country can both benefit on net at the expense of numerous "third" nations, each of which however bears only a small part of the cost. 
Moreover, there is still less evidence to suggest that traderelated investment policies currently exert an important independent influence on global patterns of production and trade, especially in relation, say, to the remaining egregious and well-documented barriers in textiles and apparel and in agriculture. As suggested above, the main effect of many investment measures at least in the medium term is to shift rents between the source and the host country.

The conventional argument for inclusion of investment measures within the GATT framework thus appears to rest on shaky ground, while any favorable influence on global efficiency of GATT efforts is in any case limited by the agreement to focus exclusively on the trade-distorting effects of such measures. Moreover, the decision to tackle investment measures primarily on the basis of their presumed role as nontariff trade distortions neglects important interactions between trade restriction and direct investment as joint determinants of the global pattern of production. Changes in trade policies have implications for foreign investment decisions; conversely, the effects of trade policies on productive efficiency and income distribution within and across countries depend crucially on the extent of induced changes in foreign investment. National investment policies can thus have an important though typically indirect influence on the consequences of 
protection and of trade liberalization. For this reason, national investment policies may indeed be critical to the success of the GATT even though these policies in themselves do not constitute important distortions of trade. Whether in the GATT or an alternative forum, the need is to evaluate the efficiency consequences of all national investment policies, not merely the subset designated as TRIMs. 


\section{NOTES}

1. As Richardson (1984, p. 2) has observed, in the new environment it is "harder to identify foreign policies, much less their effects."

Richardson uses such terms as "opaqueness" and "intricacy" to describe policies including performance requirements, tax forgiveness, credit guarantees, and implicit subsidies, noting that such policies are much more likely than straightforward trade taxes or explicit subsidies to give rise to allegations of unfairness and discrimination.

2. For example, Bergsten (1990) included a GATT for investment among four major steps to "make a quantum leap in the effectiveness of global trade arrangements."

3. See Guisinger (1987, pp. 218-219) for a comprehensive taxonomy of investment policies that classifies 46 instruments according to the specific channels through which they affect profitability.

4. Greenaway (1990) has observed that such TRIMs provide a form of insurance for the host country, raising the likelihood that anticipated benefits from an investment project will in fact materialize. As noted below, a TRIM may be binding ex ante but not ex post, i.e., after resources have been irrevocably committed to a particular project. Thus, managers of existing foreign subsidiaries may underestimate the extent to which performance requirements actually influence firm behavior. 
5. The list of TRIMs specified by the U.S. delegation to the negotiations included incentives as well as performance requirements, noting that "incentives are often granted in exchange for a specified local content level or some form of market protection" (USTR, 1987).

6. Moran and Pearson $(1987,1988)$. These papers also contain a useful comparison with data from other sources, including an unpublished study carried out by U.S. International Trade Commission.

7. Japanese automobile investments in the United States have been interpreted by Bhagwati (1985) as "quid pro quo" investments, made by foreign suppliers to forestall future protection rather than merely to benefit from anticipated future protection.

8. Most foreign direct investment, whether in terms of number or value of controlled foreign enterprises, is carried out by multinational firms that produce and sell in many countries. Cross-border investments, as between the United States and Canada, may be quite different in their characteristics from other types of FDI and may thus respond differently to national regulatory policies. Here I concentrate on the activities of multinational corporations rather than smaller bi-national ones.

9. Whether the benefits in question are those of the nation as a whole 
or of particular interest groups is a complicated issue that cannot be sorted out here. In the extreme, the entire regulatory effort may be appropriately viewed as an exercise in domestic politics, with regulators seeking to look tough rather than submissive in highly publicized confrontations with the local embodiments of foreign imperialism.

10. Economists use the term "non-economic" to describe goals that entail some sacrifice of national income in favor of other objectives, such as achieving a preferred distribution of income or self-sufficiency in a particular activity. For a further discussion of host motivation and implications for efficiency and trade, see Greenaway (1990). Recent papers by Richardson (1990a, 1990b) provide theoretical analyses of the two most important TRIMS, export incentives and local content requirements, as well as references to previous theoretical literature. Theoretical models have been helpful in comparing TRIMs to other trade distortions. However, the theoretical literature has typically abstracted from the full set of options available to globally integrated firms and host governments and has not explored the negotiated character of most investment regimes. As the discussion below suggests, the actual impact on trade of a given investment measure cannot be determined without reference to this broader decision-making context. 
11. This insight is conventionally attributed to Hymer (1960) and was promulgated by Kindleberger (1969), among others. Caves (1982) provides a comprehensive survey. On internalization as the characteristic activity of the multinational firm, see Rugman (1980) and McCulloch (1985).

12. At the margin, some location decisions may be altered merely by the division of the economy into sovereign parts. Even without an active role for policy, e.g., policies that discriminate against foreign goods or foreigncontrolled production, the extra costs of operating in two political jurisdictions may affect resource allocation. Some markets previously served by controlled local production may now be served via trade; in other cases, a local firm may now have a cost advantage over the foreign one.

13. To the extent that national policies succeed in correcting market failures or offsetting other distortions, social cost need not rise.

14. Where these motivations are important, changes in the degree of political and economic integration can either increase or decrease the extent of local production for activities characterized by scale economies. 
15. Along similar lines, Greenaway (1990) has distinguished a rentshifting target and an insurance target of host investment regimes. As used by Greenaway, the insurance target refers both to policies intended to reduce host uncertainty about future outcomes--which need not be binding--and to policies intended to alter resource allocation, especially ex ante. In all cases, some resources are absorbed in the "rent-seeking" process itself, e.g., costs of lawyers and other specialists engaged in negotiations between the firm and source or host country.

16. As Caves (1982, p. 240) has observed, "gains that host countries enjoy from taxing foreign investments have been sorely neglected in debates over MNEs....benefits and costs most commonly proclaimed either defy our best measuring instruments or are entirely conjectural; the substantial gains generated by the tax system often go unnoticed."

17. The distinction between the categories depends to some degree on the time horizon. A policy measure that simply reduces a firm's after-tax profits in the short or even medium term could influence decisions on future investments.

18. The conventional wisdom holds that protection of the local market necessarily stimulates import-competing foreign investment. This need not be the case if the erstwhile foreign suppliers lack any significant firm- 
specific advantage. Local firms rather than multinationals will then capture the protected market. The apparel industry is highly protected in all industrial countries, yet the extent of DFI is minor relative to manufacturing overall.

19. Bilateral tax treaties have dealt successfully with some of the tax issues at the national level. However, incentives are often applied at the regional or local level and are thus less susceptible to international agreements.

20. It should be emphasized that the policy process itself and the attempts of firms to shape policy and to maximize their benefits within any policy environment also use resources. Even when the location and operation of a footloose investment is in the end unaffected by competition among rival would-be hosts, the rent-seeking process may entail a substantial social cost.

21. The most obvious channel is via the host-country taxation of multinational profits. See Caves (1982, Chapter 10). However, profits may also be taxed implicitly through performance requirements imposed on foreign-controlled firms. 


\section{REFERENCES}

Bergsten, C. Fred. 1990. From Cold War to Trade War? International Economic Insights, July/August, pp. 2-6.

Caves, Richard E. 1982. Multinational Enterprise and Economic Analysis. Cambridge: Cambridge University Press.

Goldberg, Paul M., and Charles P. Kindleberger. 1970. Toward a GATT for Foreign Investment: A Proposal for Supervision of the International Corporation. Law and Public Policy in International Business, Summer, pp. 295-323.

Greenaway, David. 1990. Trade Related Investment Measures:

Political Economy Aspects and Issues for GATT. Paper presented at the NBER/CEPR International Seminar on International Trade, Cambridge, MA, August 2-3, 1990.

Guisinger, Stephen. 1986. Do Performance Requirements and Investment Incentives Work? The World Economy, March, pp. 79-96.

Guisinger, Stephen. 1987. Investment Related to Trade. In J. Michael Finger and Andrej Olechowski, eds., The Uruguay Round: A Handbook for the Multilateral Trade Neogtiations.

Washington, D.C.: The World Bank, pp. 217-225.

Hymer, Stephen. 1960. The International Operations of National.

Firms. Doctoral dissertation, M.I.T. 
Kindleberger, Charles P. 1969. American Business Abroad: Six Lectures on Direct Investment. New Haven, Conn.: Yale University Press.

Labor-Industry Coalition for International Trade (LICIT). 1981.

Performance Requirements. Washington, D.C.: LICIT, March.

Lipson, Charles. 1985. Standing Guard: Protecting Foreign Capital

in the Nineteenth and Twentieth Centuries. Berkeley, CA:

University of California Press.

McCulloch, Rachel. 1985. U.S. Direct Investment and Trade:

Theories, Trends and Public Policy Issues. In Asim Erdilek, ed.,

Multinationals As Mutual Invaders: Intra-Industry Direct

Foreign Investment. London: Croom Helm, pp. 129-151.

Moran, Theodore H., and Charles S. Pearson. 1987. Trade Related Investment Performance Requirements. Study prepared for the Overseas Private Investment Corporation. Washington, D.C.

Moran, Theodore H., and Charles S. Pearson. 1988. Tread Carefully in the Field of TRIP Measures. The World Economy, March, pp. 119-134.

Richardson, J. David. 1984. Currents and Cross-Currents in the Flow of U.S. Trade Policy. In Robert E. Baldwin, ed., Recent Issues and Initiatives in U.S. Trade Policy. Cambridge, MA: National Bureau of Economic Research, pp. 1-9. 
Richardson, Martin. 1990a. Content Protection with Foreign Capital.

Washington, D.C.: Department of Economics, Georgetown University, April.

Richardson, Martin. 1990b. Export Encouragement Schemes.

Washington, D.C.: Department of Economics, Georgetown University, August.

Rugman, Alan M. 1980. Internalization as a General Theory of

Foreign Direct Investment: A Re-Appraisal of the Literature.

Weltwirtschaftliches Archiv 116, pp. 365-79.

Safarian, A. E. 1983. Trade-Related Investment Issues. In William R.

Cline, ed., Trade Policy in the 1980s. Washington, D.C.:

Institute for International Economics, pp. 611-637.

Spero, Joan Edelman. 1981. The Politics of International Economic

Relations. New York: St. Martin's Press.

U.S. Department of Commerce. 1981. The Use of Investment

Incentives and Performance Requirements by Foreign

Governments. Washington, D.C.: Office of Intemational Investment, International Trade Administration, October.

United States Trade Representative. 1987. Submission of the United States to the Negotiating Group on Trade-Related Investment Measures. 